\title{
Scientifically Correct Racism: Health Studies' Unintended Effects against Minority Groups
}

\author{
Daniel La Parra Casado and Miguel Angel Mateo Pérez \\ Dpto. Sociología II, University of Alicante, Alicante, Spain
}

The present paper analyses press releases, news reports and health plans to show how health communication functions in perpetuating dominant racist structures. The paper is mainly concerned with how normal science and health practices can become an instrument for justifying racism and reproducing it in our societies. The examples demonstrate that even when all forms of explicit racism are avoided, health communication can have identifiable racist consequences in people's lives.

La comunicación sobre temas de salud tiene un papel importante en la construcción de una realidad social caracterizada por la clasificación jerárquica de los seres humanos a partir de la idea de 'raza'. El artículo analiza los textos de planes de salud, de notas de prensa y noticias para mostrar como la circulación de la información entre instituciones de salud y medios de comunicación tiene el efecto de reproducción de las estructuras racistas dominantes. El manuscrito se centra en la forma en que la ciencia y la práctica ordinaria sobre la salud pueden acabar legitimando formas de racismo. La atención se centra en la identificación de efectos racista no intencionales, esto es, aquellos que se producen incluso cuando se evitan las formas de racismo explícito.

doi: $10.2167 /$ laic271.0

Keywords: health communication, immigrants, mass media, minorities, racism

Over the past few centuries, science has contributed directly to the formation of an idea of 'race' and to legitimising racist practices, especially in the fields of genetics, anthropometrics, health and intelligence (Bhopal, 1998, 2001). This is a consequence of biased interpretations of inconclusive results. At present, the scientific community has become more aware of this pseudoscientific activity, and has taken fairly active measures to avoid giving credence to its outputs. An indicator of the success of these measures is that it is becoming more and more difficult to find explicit forms of racism in researchers' public discourse. Because of this, the main theme of this paper might sound strange: what we affirm is that normal practice in the field of health studies is contributing to the production of racism in our societies. Health researchers have an important role in the construction of a social reality characterised by a hierarchical stratification of human beings that is also based on 'race' classifications. We are suggesting that normal science - objective (meaning 'inter-subjective') and neutral - could become an instrument for justifying racism. At the same time, and although it may appear to be a contradiction in terms, we would like to 
stress that health researchers and professionals play this game without being overtly racist; in fact, most of them may even be openly antiracist. To explain this, we need to analyse what racism is.

Racism could be defined as the belief that some human beings (a 'race') are superior to other social groups (called 'races'). Ethnicism proceeds in a similar way, but this time, using hierarchical definitions of culture instead of 'race'. Oddly enough, the word 'ethnic' is frequently assigned to the non-white. (Jackson, 1999: 31)

Prejudices, stereotypes, insults, pejorative labels and other things are usually expressed in racist discourses. Explicit racism helps to legitimise individual and collective action that creates and sustains inequality and oppression between social groups. Together with this, individual and collective actions also reproduce a hierarchical racialised world. The history of mankind provides thousands of examples of racist violence: genocide, colonialism, repressive immigration policies and all kinds of discriminatory behaviour. This kind of racism is explicit and visible.

Unfortunately, racism can also be invisible. Racism is totally embedded in the social structures and in the social representation of the world and, as a consequence of this, minority groups are still discriminated against even in countries where civil rights are recognised and antiracist policies are implemented. Statistical data, when they exist, show systematically that minority groups throughout the world have difficulty gaining access to education, health, income, wealth, good jobs, political representation and mass media, amongst many other social resources including the right to a positive self-image. Without taking into account the structural component of racism, antiracist initiatives may end up as well meaning but naïve projects.

The consequences of collective social action (public institutions, the mass media, the labour market, public policies, economic organisation, scientific production, the educational system, communications and transport, and others) are not obvious. As social actors, we participate in the dynamics of society without being fully aware or conscious of the effects we produce. The sometimes unintended effects of collective action tend to disadvantage minority groups. For instance, if in a given country access to health care is determined by private insurance cover, social groups in a weaker socioeconomic position will find themselves excluded. Even if the private cover policy is not driven by explicit racist discourse, minority groups will be affected, especially if the group has historically suffered other forms of direct violence (like slavery) and discrimination (for a discussion about race and the underdevelopment of the US welfare state, see Manza, 2000).

We consider the unintended effects of normal scientific activity and health care to be one of the most important sources of the legitimisation and reproduction of social structures (Van Dijk, 2003). We focus here on two main communication channels used to transmit health messages: mass media and official documents. 
(1) Mass media. Physicians and health authorities have direct access to the mass media and therefore can indirectly influence the population's behaviour when a health emergency arises. In the following pages we exemplify this with the recent episode of Severe Acute Respiratory Syndrome (SARS). This example identifies some key structural elements in the communication process in relation to race and disease outbreak. These elements may be similarly applied to other outbreaks of established and emergent diseases such as AIDS, Ebola and avian influenza.

(2) Official documents. Health workers and researchers have a decisive influence on the health care system: they define the clinical encounter, they design health care facilities and they shape legal, regulatory and health policy interventions. In this paper we analyse official health plans in order to identify how immigrants and minority groups are considered in health system planning documents.

Our main aim is to analyse press releases, newspapers and health plans to show how functional the communication is for dominant structures. We are not interested (in this case) in linguistics, rhetoric, style, or lexical or grammatical issues, but in the implications of health communication for people's lives, especially when the discourse avoids all forms of explicit racism.

\section{Mass Media Messages About Health: The Example of SARS}

According to the World Health Organization (WHO) official report on severe acute respiratory syndrome (SARS) (WHO, 2003b), Chinese authorities first reported an outbreak of atypical pneumonia in Guandong Province to the WHO on 11 February 2003. Around 30\% of the cases were reported to affect health care workers. Apparently, a doctor who had treated patients in his home town on February 21 carried the virus out of Guandong. He brought the virus to a four-star hotel in Hong Kong, and days later, guests and visitors to the hotel had seeded outbreaks of cases in hospitals in Hong Kong, Vietnam and Singapore. At the same time, the disease began spreading to Toronto in Canada, and to up to 30 other countries around the world along international air travel routes, mainly carried by hotel guests and other medical doctors who treated the earliest cases. Health care workers fighting to save their patients' lives in the initial 'hot zones' of SARS were unwittingly exposed to the virus. This could explain the chains of secondary transmission outside the health care system. On 31 July 2003 the cumulative global total was 8096 probable cases and 774 deaths (WHO, 2003c). The effective strategies for stopping the disease were the prompt detection of cases, immediate isolation, strict infection control and contact tracing.

During this time, a different history of the disease was occurring around the world. In Toronto, Cynthia Pay, the executive vice president of the Chinese Canadian National Council, lamented that 'what we're seeing now is hysteria and over-reaction associating disease with the Chinese community', referring to cases of Chinese (and other people with Asian features) being singled out 
for special treatment at school, being shunned in public transport and suffering forms of racism on a daily basis (Schram, 2003). In Spain, the newspaper El País (5 May 2003) reported that five asymptomatic Asian immigrants, who were travelling with 88 other immigrants from different African countries and intercepted on their attempt to reach the European continent in small illegal boats, had been held in isolation by police authorities and had undergone special medical examinations. At the same time, following the WHO recommendations, international air travellers arriving in Madrid from affected areas (WHO, 2003a) were asked to fill in questionnaires without compulsory medical examinations (El País, 19 March 2003).

The two versions are remarkably different. On the one hand, there is a disease outbreak in China that spreads by international air travel routes mainly affecting heroic and unaware health workers, tourists, business people and their families. On the other, Asians suffered stigmatisation and racism, regardless of whether or not they had travelled to affected areas in the preceding days or had worked in a health care centre. It is noteworthy that the above-mentioned Asian immigrants in Spain were isolated even when isolation as a control measure was recommended only for probable cases. As we said, they were asymptomatic and were travelling from Africa, a continent with only one probable case, reported in South Africa. We propose three complementary explanations for these two tales of a disease.

First, we can categorically say that the writing process of a novel belongs to its author and interpretation to its audience. Likewise, neutral and disinterested information about the onset of the disease in Asia was transformed by the public into a disease associated with the Asian minority. This time the writer failed to give a good title to his/her novel. The disease was called either 'atypical pneumonia' or 'Asian pneumonia'. The mass media diffusion of this message, saturating us with images of Asians wearing masks, reinforced the association with Asians. Fortunately, the disease was later given a more specific name: Severe Acute Respiratory Syndrome. Questions of reception are crucial: meanings do not spring directly from textual features but are appropriated by the mass media and the population through their practices of appropriation and reception (Briggs, 2005). Nevertheless, at other times the history of the beginning of a disease has been worse, as is witnessed by the repercussions of the designation by the Center for Disease Control (CDC), USA, of Haitians as a risk group for AIDS (Farmer, 2003, Schram, 2003).

Secondly, the actors involved in the history of SARS have different capabilities of producing public discourse. We have mentioned health workers, international air travellers (mainly tourists and business people), minority groups and immigrants. These social actors have different resources for reaching the mass media. For instance, physicians are usually considered well informed voices; they master the local language, have a high social status and know of strategies to access the media, such as press conferences, scientific journals, etc. By contrast, immigrants tend to be shown in the media as passive recipients of actions; they are rarely interviewed to give direct information, and face more barriers to the production of a positive message. This power imbalance plays a decisive part in the stigmatisation process. Even if nobody produces an explicit discourse against immigrants and ethnic 
minorities, they are unable to protect themselves from widespread ideas that associate immigration and disease. Furthermore, researchers or health authorities will not counteract these ideas while they consider health workers a 'risk group' for a given disease. ${ }^{1}$ As Briggs (2005) reminds us, in the game of communication some people are producers of knowledge, others are translators and disseminators, other are receivers, and some are simply out of the game. In the present case, the ethnic minorities and immigrants were merely used as the raw material for news stories.

Thirdly, different governmental authorities acted inconsistently at a time of great confusion due to an emergent and poorly understood disease. As the WHO has stated,

SARS caused considerable social disruption and public anxiety, even in areas well beyond the outbreak sites. Hospitals, schools and some borders were closed. Thousands of persons were placed in voluntary or supervised quarantine. Avoidance of travel to certain areas was disproportionate to the risk, as was the widespread wearing of surgical masks. Patients and ethnic groups encountered discrimination. (WHO, 2004)

Errors and a certain degree of ambiguity can be expected in a context of widespread public anxiety and lack of knowledge, but it is fair to recognise that our bias tends to be consistent with 'our old colonialist minds'. Thus, authorities have been more specific in giving travel advice about Hong Kong or Vietnam than about Canada. At the same time, Canadian authorities had more power and resources to protect their image. Let us remember the Mayor of Toronto opposing the April $23 \mathrm{WHO}$ travel advisory to Toronto:

'They've never issued an advisory like this before in their history,' Toronto's mayor sputtered at a press conference, adding, 'I've never been so angry in my life.' (CBC News, 24 April 2003)

His protest was broadcast by many international mass media. The travel advisory was withdrawn by the WHO on 29 April (WHO, 2003f). According to Dr. Brundtland, Director-General of the WHO, there were three changes in Toronto over the last week: the magnitude of probable SARS cases has decreased; twenty days have passed since the last cases of community transmission occurred and no new confirmed exportation of cases has occurred' (WHO, 2003f). However, on 29 April Toronto was still an 'affected area', defined as a region reporting a local transmission of SARS within the last 20 days (WHO, 2003d) (it was temporarily removed from the list on 14 May and definitively on 2 July 2003).

The decisions affecting Hanoi took more time. Vietnam was the first country to successfully contain the disease and because of this they were removed from the affected areas list on 28 April 2003 (WHO, 2003e):

WHO has today removed Vietnam from the list of affected areas, making it the first country to successfully contain its SARS outbreak. The change in Viet Nam's status follows 20 consecutive days (the duration of two incubation periods) since the last new case was detected. (WHO, 28 April 2003) 
WHO advised travellers to Beijing and Shanxi Province, China, and Toronto, Canada to consider postponing all but essential travel on April 23. In its April 29 press release it continued not to mention Vietnam in its travel advice list, so the world community would presumably have understood that there was no problem in travelling to that country:

Travel advisories for Beijing, Hong Kong SAR, and Guangdong and Shanxi provinces, China, remain in effect. (WHO, 29 April 2003)

However the CDC in the USA downgraded its travellers' notification for Hanoi and Toronto from a travel advisory to a travel alert the same day (on 30 April 2003) and only removed its travel alert for Hanoi on 15 May 2003 and for Toronto on 20 May 2003, because more than 30 days had elapsed since the last SARS symptoms were reported.

In general, we tend to overreact to events coming from Asia, Africa, South America or 'ethnic-racial' minorities in Europe and North America, and to be less anxious when problems come from Europe and North America. The same could be said for the dichotomy immigrants/professionals. Fortunately, many public health authorities, including the WHO, have been very effective in producing clear, factual and reassuring messages, but this has not been enough to avoid discrimination. Strategic elements about how to work with mass media, and national and local authorities, must be reinforced in future protocols designed to manage emergent diseases.

\section{Internal Communication Within the Health System: Health Plans}

Health policy is the result of the collective work of researchers, physicians, politicians, other health workers and sometimes the community. Health policies, according to a WHO proposal (WHO, 1991), must be made public in official papers known as 'Health Plans'. These reports contain their guiding principles, describe their specific objectives and define the actions to be taken to achieve them. Therefore, they show the government rhetoric about reducing the inequalities in health care that affect minority groups and immigrants.

The data that follow were obtained in a content analysis study of health plans in Spain. Our aim was to describe how immigrants and other ethnic groups (mainly Romany people or Gypsies) appeared in 14 Autonomous Communities $^{2}$ Health Plans (three Communities do not have any available plan at the moment of writing). We listed all references to immigrants, gypsies, and more specifically, to Ecuadorians and Moroccans, the largest national groups within the immigrant population. content Textpack $\mathbb{C}$ analysis software and Word $(\mathbb{C}$, Netscape $(C)$ and Acrobat $(\mathbb{C}$ word search tools were used to list the terms.

The results speak for themselves. To summarise our findings, we found 125 references to immigrants and minority groups in a total of 3402 pages: 7 of them talking about Moroccans, 3 about Ecuadorians and only 6 referring to Gypsies.

Focusing on immigrants, there were up to 64 references related to specific health problems (see Table 1): 21 of them refer to tuberculosis, 10 to HIV/ 
AIDS, 8 to sexually transmitted diseases and 7 to vaccination; cancer, accidents and cardio-cerebrovascular diseases together amounted to 3 more. The remaining 15 refer to health problems like malaria, hepatitis, domestic violence, health habits, mental and dental health, and child and maternal health. In fact, a glance at the biomedical literature about immigrants and health confirms that studies about AIDS, tuberculosis and sexually transmitted diseases are overrepresented compared to cancer or cardiovascular diseases. ${ }^{3}$

In addition, immigrants were mentioned in chapters about demographic estimations (15 references), in sentences describing them as a group living in poverty or suffering social disadvantage (19 references), in 7 bibliographic references and 8 times in paragraphs about access to health services. They were usually found in sections dealing with 'excluded social groups' such as sex workers, drug addicts or homeless people who normally are also stigmatised.

Table 1 Classification of references related to specific health problems of immigrants. Content analysis of 14 Spanish Health Plans ${ }^{a}$

\begin{tabular}{|l|r||}
\hline Topics & N \\
\hline Social inequalities & 19 \\
\hline Health services access & 8 \\
\hline Demographic issues & 15 \\
\hline Health problems & 64 \\
\hline Tuberculosis & 21 \\
\hline HIV/AIDS & 10 \\
\hline Sexually transmitted diseases & 8 \\
\hline Vaccination & 7 \\
\hline Other communicable diseases & 4 \\
\hline Child and maternal health, dental, mental & 8 \\
\hline Cancer, cardio- and cerebrovascular diseases & 3 \\
\hline Other problems & 719 \\
\hline Bibliography & 6 \\
\hline Other topics & 3 \\
\hline Total & 3 \\
\hline
\end{tabular}

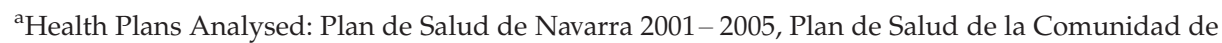
Castilla y León 1998- 2007, Plan de Salud de Canarias 1997-2001, III Plan Andauz de Salud 20032008, Pla de Salut de Catalunya 2002-2005, PlaN de Salut de les Illes Balears 2003-2007, Plan de Salud de Aragón 1999-2003, Plan de Salud de Castilla-La-Mancha 2001-2010, Plan de Salud de Extremadura 2001-2004, Plan de Salud de Galicia 2002-2005, Plan de salud de la Comunidad Autónoma de la Región de Murcia 2003- 2007, Plan de Salud de la Comunidad Valenciana 20012004, Plan de Salud Para Asturias 2004-2007, Políticas de Salud para Euskadi 2002- 2010. 
It would appear, then, that health planners, guided by principles of equity, do not take into account traditional minority groups like the Gypsies ${ }^{4}$ when they are planning health strategies. However, immigration processes are slowly becoming an emergent topic in health planning. The information is scarce and based on low quality data: only 7 bibliographic references.

Immigrants are treated as a socially excluded, homogeneous group. The documents analysed do not allow for diversity within the immigrant population, in terms of nationality, gender, socioeconomic position or other criteria. The demographic data, together with information about communicable diseases, picture immigrants as a dangerous threat to local population health. In other words, they are ignored by health planners when dealing with prevalent and lethal diseases, and stigmatised when they are on the scene.

The discourse is not openly racist in its expression, but it can be racist in its consequences. During the last decade over two million immigrants have arrived in Spain, but health planners, excepting those of Asturias and Andalusia, have not devised general strategies for improving health care for them. None of the health plans assessed has estimated the resources contributed or demanded by this new population. As a result, their access to health services could be hindered (La Parra, 2004). Another consequence, according to Rodriguez (2002), is fiscal inequity: immigrants are estimated to contribute to the inland revenue twice the amount they receive in terms of social and health benefits.

\section{Conclusions}

Scientists, health planners and health workers produce and/or use scientific knowledge to guide their actions. However, research instruments, empirical evidence and rational discussion do not seem enough to avoid racist consequences. This is true of practice, research and dissemination of information. The communicability approach suggested by Briggs could be useful to understand the way social communication reflects the structure of power (Briggs, 2005). This approach takes into account the synergies, but also the differences of power between the different actors involved in the communication process: the producers (researchers), translators (health authorities), disseminators (mass media), receivers (people) and excluded (immigrants, ethnic minorities). The following recommendations may be helpful in developing an antiracist agenda capable of promoting a less oppressive communication system:

(1) Adoption of a proactive attitude against direct and structural forms of racism. A 'neutral' attitude may not be enough to overcome racialised social structures. As Witkin (2000) has proposed, human rights should be considered as research and practice goals, and that means fighting inequalities in health.

(2) Critical assessment of previous and established knowledge. We are embedded in a historical and cultural context, both at the macro level of social structures and at the micro level of personal beliefs. This context 
determines the concepts we use, the implicit values of science and practice, and the way we understand social reality.

(3) Health as an individual human right. Disease is suffered by individuals, regardless of the social group they identify themselves with. Nevertheless, each one of us assesses the implications of disease depending on the social group we belong to. If a person is a member of the exogroup, he/she may be seen as a potentially infectious agent, rather than as someone infected. Nationalism, as one of the most powerful identification processes, could add force to this unconscious way of thinking. Religion, language, ideology, traditions and other factors could also work in the same direction. It is important to acknowledge their importance as positive elements for us, but we must be careful to prevent these rich cultural resources from becoming instruments for justifying discrimination.

(4) Changes in power structures within health care and research institutions. All social groups should share health research and practice, giving priority to those in a disadvantaged position. Institutions must guarantee the participation of all groups in this. This involves radical changes in the distribution of capital and power in the production, dissemination and distribution of knowledge about health and disease (Briggs, 2005).

These recommendations are not easy to follow; even the present paper is not entirely free of the regressive assumptions that frame everyday thinking and discourse on health. Even so, we hope to have raised awareness of an important issue, no matter how difficult it will be to resolve.

\section{Correspondence}

Any correspondence should be directed to Daniel La Parra, Dpto. Sociología II, Universidad de Alicante, ap. correos 99, 03080 Alicante, Spain (daniel.laparra@ua.es).

\section{Notes}

1. In our opinion the label 'risk group' is not valid, either for physicians or any other social group.

2. Spain's 17 autonomous communities (Catalonia, Basque Country, Andalusia, Madrid, etc.) have wide legislative and executive autonomy, with their own parliaments and regional governments.

3. Statement supported by a literature search using the PubMed database (on 7 September 2004) - National Center for Biotechnology Information (NCBI) (http:// www.ncbi.nlm.nih.gov) at the National Library of Medicine (NLM) (http:// www.nlm.nih.gov) - combining different MeSH terms - NLM's controlled vocabulary used for indexing articles for MEDLINE/PubMed. The combination of 'emigration and immigration' $\mathrm{MeSH}$ term with 'tuberculosis' [MeSH] produced 776 results, with 'HIV infectious' [MeSH] 584 results, with 'neoplasms' [MeSH] 338 results and with 'cardiovascular diseases' $[\mathrm{MeSH}]$ only 242 results. This kind of information should not be considered conclusive without a more careful review of the retrieved results. For further information about PubMed database search instructions, please visit PubMed (2004).

4. The Romany people have lived in Spain for over five centuries and they number about half a million. 


\section{References}

Bhopal, R. (1994) Ethnicity as a variable in epidemiological research. British Medical Journal 309, 327-330.

Bhopal, R. (1998) Spectre of racism in health and health care: lessons from history and the United States. British Medical Journal 316, 1970-1973.

Bhopal, R. (2001) Racism in medicine. British Medical Journal 322, 1503-1504.

Bhopal, R. (2004) Glossary of terms relating to ethnicity and race: For reflection and debate. Journal of Epidemiology and Community Health 58, 441-445.

Briggs, Ch.L. (2005) Communicability, racial discourse, and disease. Annual Review of Anthropology 34, 269-291.

Carballo, M., Divino, J.J. and Zeric, D. (1998) Migration and health in the European Union. Tropical Medicine \& International Health 3 (12), 936-944.

Farmer, P. (2003) Pathologies of Power. Health, Human Rights and the New War on the Poor. Berkeley: University of California Press.

Gee, G.C. (2000) Multilevel analysis of the relationship between institutional and individual racial discrimination and health status. American Journal of Public Health 92, 615-623.

Jackson, R.L. (1999) The Negotiation of Cultural Identity: Perceptions of European Americans and African Americans. Westport: Praeger, Greenwood.

Karlsen, S. and Nazroo, J.Y. (2002) Relation between racial discrimination, social class and health among ethnic minority groups. American Journal of Public Health 92, 624-631.

La Parra, D. (2004) Violencia estructural y migración: las instituciones sociales en España. In Hidalgo, F. (ed.) Migraciones (pp. 233-255). Quito: Abya-Yala.

Lewontin, R.G., Rose, S. and Kamin, L. (1987) No está en los genes: racismo, genética e ideología. Barcelona: Crítica.

Manza, J. (2000) Race and the underdevelopment of the American welfare state. Theory and Society 30, 819-832.

McKay, L., Macyntire, S. and Ellaway, A. (2003) Migration and health: A review of the international literature. Glasgow: Medical Research Council Social and Public Health Science Unit.

McKenzie, K. (2003) Racism and health. British Medical Journal 326, 65-66.

Mead, M. (ed.) (1968) Science and the Concept of Race. New York: Columbia University Press, American Association for the Advancement of Science.

NCBI, National Center for Biotechnology Information (2004) PubMed database. On WWW at http://www.ncbi.nlm.nih.gov. Accessed 9.06.

Pearce, N., Foliak, S., Sporle, A. and Cunningham, Ch. (2004) Genetics, race, ethnicity, and health. British Medical Journal 328, 1070-1072.

Rodríguez, C.B. (2002) La asistencia a los inmigrantes: entre el mito y la realidad. Revista española de economía de la salud November-December, 16-18.

Schram, J. (2003) Personal view: How popular perceptions of risk from SARS are fermenting discrimination. British Medical Journal 326, 939.

Smedley, B.D., Sthith, A.Y. and Nelson, A.R. (eds) (2003) Unequal Treatment. Confronting Racial and Ethnic Disparities in Health Care. Washington: The National Academic Press.

Torres, A.M. and Sanz, B. (2000) Health care provision for illegal immigrants: should public health be concerned. Journal of Epidemiology and Community Health 54, $478-479$.

UNESCO (1983) Racism, Science, and Pseudo-Science: Symposium to Examine PseudoScientific Theories Invoked to Justify Racism and Racial Discrimination. Athens: UNESCO.

Van Dijk, T.A. (2003) Racismo y discurso de las élites. Barcelona: Gedisa.

WHO, World Health Organization (1991) Objetivos de salud: salud para todos en el año 2000. Geneva: WHO. 
WHO, World Health Organization (2003a) Affected Areas - Severe Acute Respiratory Syndrome. On WWW at http://www.who.int/csr/sars/areas/2003_04_21/en/. Accessed 09.06.

WHO, World Health Organization (2003b) Severe Acute Respiratory Syndrome (SARS). Status of the outbreak and lessons for the immediate future. Geneva: WHO Communicable Disease Surveillance and Response.

WHO, World Health Organization (2003c) Summary of probable SARS cases with onset of illness from 1 November 2002 to 31 July 2003. On WWW at http:/ / www.who.int/ csr/sars/country/table2004_04_21/en/. Accessed 09/06.

WHO, World Health Organization (2003d) Summary table of areas that experienced local transmission of SARS during the outbreak period from 1 November 2002 to 31 July 2003. On WWW at http://www.who.int/csr/sars/areas/areas2003_11_21/en/. Accessed 09.06.

WHO, World Health Organization (2003e) Update 41-Viet Nam removed from list of affected countries, more than 5000 probable cases worldwide. On WWW at http:/ / www.who.int/csr/sarsarchive/2003_04_28/en/. Accessed 09.06.

WHO, World Health Organization (2003f) Update 42-Travel advice for Toronto, situation in China, 29 April 2003. On WWW at http://www.who.int/csr/sars/ archive/2003_04_29/en/.09.06.

WHO, World Health Organization (2004) Severe Acute Respiratory Syndrome (SARS). Report by Secretariat. Executive Board. 113th Session, 23 January 2004, Agenda item 8.3 EB113/33 Rev.1.

Wieviorka, M. (1992) El espacio del racismo. Barcelona: Paidos.

Witking, S.L. (2000) An integrative human rights approach to social research. In C. Truman, B. Humphries and D.M. Mertens (eds) Research and Inequality (pp. 205-219). London: University College London.

Witzig, R. (1996) The medicalization of race. Scientific legitimization of a flawed social construct. Annals of Internal Medicine 125, 675-679.

Zuckerman, J.N. (2002) Travel medicine. British Medical Journal 325, 260-264. 